\title{
Occurrence of the $M$ Substance of Type 28 Group $A$ in Streptococci of Lancefield Groups B, C and G
}

\author{
BY W. R. MAXTED \\ Streptococcal Reference Laboratory, Central Public Health \\ Laboratory, Colindale, London
}

SUMMARY: Strains of streptococci belonging to Lancefield groups B, C and G were found to possess an antigen which is identical with the group A type $28 \mathrm{M}$ antigen in its ability to absorb group A type 28 antibodies, and to stimulate the production of type 28 antibodies. The antigen also resembles the group $\mathbf{A}$ type 28 antigen in its sensitivity to pepsin and trypsin, being inactivated by pepsin but not by trypsin. The antigen does not appear to be the major type-specific antigen in some of the strains not belonging to group $A$.

Lancefield (1940) showed that the serological types of group A streptococci are each characterized by the possession of a type-specific protein antigen, the M substance. Occasionally, $\beta$-haemolytic streptococci are encountered which, although belonging to groups other than $\mathrm{A}$, react with absorbed type-specific sera prepared against group A organisms. The nature of the antigen responsible for this cross-relationship has not so far been determined. It is the purpose of this paper to describe four such strains, one of which belonged to group B, two to group $\mathrm{C}$ and one to group $\mathrm{G}$; all four strains had the $\mathrm{M}$ antigen characteristic of type $\mathbf{2 8}$ group $\mathbf{A}$.

\section{Material and Methods}

Source of strains. Strain 'Small' was Griffith's original group A type 28; strain 3962 group B came from a patient with a mild sore throat; strain D10 group $\mathrm{C}$ was also isolated from a sore throat. Strains 6074 group C and J23 group $\mathbf{G}$ came from the vaginae of patients with puerperal fever.

Cultures. For extraction or enzyme treatment the cells after $20 \mathrm{hr}$. incubation at $37^{\circ}$ in $50 \mathrm{ml}$. of broth (Todd \& Hewitt, 1932), were collected by centrifugation.

Preparation of extracts. Crude $\mathrm{HCl}$ extracts were prepared as described by Lancefield (1940). These extracts contained the group-specific $\mathrm{C}$ substance and the type-specific $M$ antigen.

Precipitation reactions. The capillary technique of Swift, Wilson \& Lancefield (1943) was used throughout.

Preparation and absorption of antisera. Antisera were prepared by inoculating rabbits with formalin-killed streptococci using a slight modification of Lancefield's technique. The strains were passaged a number of times through mice, and after confirming the presence of type $28 \mathrm{M}$ substance, $250 \mathrm{ml}$. amounts of Todd-Hewitt broth were inoculated and incubated for $24 \mathrm{hr}$. at $37^{\circ}$. Formalin was then added to a concentration of $0 \cdot 2 \%(\mathrm{v} / \mathrm{v})$, and the flasks were left for $48 \mathrm{hr}$. at room temperature. The cultures were then centrifuged, the deposit 
washed once in saline and concentrated by suspending in $17 \mathrm{ml}$. of $0.2 \%$ formol saline. Rabbits were given $0.5 \mathrm{ml}$. intravenously as a primary dose, rested 1 week, and then given $1.0 \mathrm{ml}$. on each of 3 successive days, and again rested for 1 week. After 8-10 weeks good precipitating sera were obtained. Three rabbits receiving the group $\mathbf{G}$ strain died before large bleedings could be taken; the smaller samples, however, gave good precipitation after absorption with a heterologous group $\mathrm{G}$ strain. All sera were absorbed with a heterologous strain of the same group to remove non-specific antibodies, the absorbing dose being 1 part of packed centrifuged deposit of cocci to 4 parts undiluted serum.

\section{The absorption of the type-specific antibodies from the group $A$ type 28 serum by related strains of other groups}

The type 28 serum made with strain 'Small' was absorbed with type 3 coeci to remove non-specific antibodies. Strains 'Small' and 3962, D10 and J23 were then each used to absorb separate samples of the serum. Four control samples were absorbed each with a strain of either group $\mathbf{A}, \mathbf{B}, \mathbf{C}$ or $\mathbf{G}$ but unrelated to type 28; the samples were then tested for precipitins with extracts of strain 'Small' and of the other group strains related to it (Table 1). All the strains precipitating with type 28 serum removed the group A type 28 antibodies. The control samples retained their activity.

Table 1. Precipitin reactions of a group A type 28 antiserum absorbed by strains of cocci containing the type 28 antigen, but belonging to various groups

\begin{tabular}{lccccc} 
M extracts prepared & \multicolumn{5}{c}{ Antiserum absorbed by strain } \\
from strain & $\begin{array}{c}\text { Group A } \\
\text { type 3 }\end{array}$ & Group A & Group B & Group C & $\begin{array}{c}\text { Group G } \\
\text { 'Small' }\end{array}$ \\
'Small', group A & $++1++*$ & - & - & - & - \\
D 10, group C & $++1++$ & - & - & - & - \\
3962, group B & $+1+$ & - & - & - & - \\
J 23, group G & $+1+$ & - & - & - & - \\
6074, group C & $++1++$ & - & - & - & -
\end{tabular}

* The readings before the stroke were made after $2 \mathrm{hr}$. at $37^{\circ}$; those following the stroke after a further $24 \mathrm{hr}$. at $4^{\circ}$. Absorption with one strain of each group unrelated to type 28 failed to remove the precipitating antibody.

$+=a$ light uniform precipitate up the whole fluid column in the capillary tube.

$++=\mathbf{a}$ definite floceulation.

$+++=$ heavy precipitate at the base of the column.

$-=$ no precipitate.

\section{Effect of trypsin and pepsin on $M$ extracts}

Lancefield (1943) has shown that the type-specific M substance of type 28 differs from the $M$ substance of all the other types, except type 44, in that it resists the action of trypsin, though it is inactivated by pepsin. All other known $M$ antigens in group $A$ except type 44 are inactivated by trypsin as well as by pepsin. Therefore in order to identify further the type 28 antigen of these 
group B, C and G strains, the action of pepsin and trypsin on their serological reactivity was investigated.

Duplicate samples of the centrifuged bacterial deposit were resuspended in $15 \mathrm{ml}$. amounts of either acetate buffer $\mathrm{pH} 2.5$ or phosphate buffer $\mathrm{pH} 8.4$. To the cells suspended in $\mathrm{pH} 2.5$ buffer was added either pepsin in water to give a concentration of $1 \%$, or water; to the cells in $\mathrm{pH}$ buffer 8.4 was added

Table 2. Precipitation reactions between type $28 M$ antibodies and $M$ extracts, demonstrating inactivation by pepsin but not by trypsin

\begin{tabular}{|c|c|c|c|c|}
\hline \multirow[b]{2}{*}{$\begin{array}{l}\text { M extract prepared } \\
\text { from strain }\end{array}$} & \multicolumn{4}{|c|}{$\begin{array}{l}\text { Preliminary treatment of cells before preparation } \\
\text { of } M \text { extract }\end{array}$} \\
\hline & $\begin{array}{l}\mathrm{pH} 8.4 \text { buffer } \\
\text { and trypsin }\end{array}$ & pH 8.4 buffer & $\begin{array}{l}\text { pH } 2.5 \text { buffer } \\
\text { and pepsin }\end{array}$ & pH 2.5 buffer \\
\hline $\begin{array}{l}\text { Small', group A type } 28 \\
3962 \text {, group B } \\
\text { D 10, group C } \\
\text { J 23, group G }\end{array}$ & $\begin{array}{l}++1++* \\
++1++ \\
++1++ \\
++1++\end{array}$ & $\begin{array}{l}++1+++ \\
++1++ \\
++1++ \\
++1++\end{array}$ & $\begin{array}{l}-1- \\
-1- \\
-1 \operatorname{tr} \\
-1-\end{array}$ & $\begin{array}{l}++1++ \\
++1++ \\
++1++ \\
++1++\end{array}$ \\
\hline
\end{tabular}

either trypsin in water to give a concentration of $1 \%$, or water. The mixtures were incubated for $72 \mathrm{hr}$. at $37^{\circ}$, centrifuged and the deposits washed in saline. $M$ extracts were made from each washed sample and tested for precipitation against group A type 28 serum. It will be seen (Table 2) that the serological reactivity of the $M$ antigen from each strain was destroyed by pepsin and not by trypsin.

The results of the absorption and enzyme digestion tests suggested that it would be possible to prepare from these strains antisera which would precipitate with the M extract from group A type 28 strain 'Small'.

\section{Production of type $28 M$ antisera for strains $3962, D 10$ and $J 23$}

The serum obtained after 8-10 weeks gave good precipitation with extracts of the immunizing strain. Samples of each serum were absorbed with a heterologous strain of the same group, to remove non-specific antibodies, then tested against extracts of $(a)$ all the group A type strains, $(b)$ other strains of the same group, and $(c)$ all the strains showing relationship with type 28. All these sera reacted well with all the strains which had precipitated the group A type 28 serum (Table 3 ). No cross-reactions occurred with extracts of any of the other group A types, or with extracts of unrelated strains belonging to homologous or heterologous groups. The antisera so produced were after absorption indistinguishable from that produced by the group $\mathbf{A}$ type 28 strain 'Small'.

\section{The demonstration of another precipitating antibody in the serum made with group $C$ strain $D 10$}

It seemed possible that the sera contained another precipitating antibody type-specific within the particular group. An attempt was made to demonstrate this in the antiserum made to strain D10 group C. The group C non-specific 
Table 3. The specific antigenicity of type $28 M$ substances in strains of Str. pyogenes groups $B, C$ and $G$

\begin{tabular}{|c|c|c|c|c|}
\hline \multirow[b]{2}{*}{$\begin{array}{l}\text { M extract prepared } \\
\text { from strain }\end{array}$} & \multicolumn{4}{|c|}{$\begin{array}{l}\text { Precipitin reactions with serum from rabbits } \\
\text { immunized with strain }\end{array}$} \\
\hline & $\begin{array}{l}\text { 'Small', } \\
\text { group A }\end{array}$ & $\begin{array}{l}3962, \\
\text { group B }\end{array}$ & $\begin{array}{l}\text { D 10, } \\
\text { group C }\end{array}$ & $\begin{array}{l}\mathbf{J} 23, \\
\text { group } \mathrm{G}\end{array}$ \\
\hline types $1-30$, and types 44 & $-1-*$ & $-1-$ & $-1-$ & $-1-$ \\
\hline $\begin{array}{l}\text { group B; 'Azgazardah', } \\
\text { C; 'Goodman', group G }\end{array}$ & $-1-$ & $-1-$ & $-1-$ & $-1-$ \\
\hline $\begin{array}{l}\text { group A type } 28 \\
\text { oup B } \\
\text { oup } C \\
\text { up G }\end{array}$ & $\begin{array}{c}++1+++ \\
+1++ \\
++1+++ \\
+1++\end{array}$ & $\begin{array}{l}+1+++ \\
+1++ \\
+1++ \\
-1++\end{array}$ & $\begin{array}{c}++1+++ \\
+1++ \\
++1+++ \\
+1+++\end{array}$ & $\begin{array}{l}+1++ \\
+1++ \\
+1++ \\
+1++\end{array}$ \\
\hline
\end{tabular}

* Symbols as in Table 1.

antfbodies were absorbed with strain 'Azgazardah' group C type 7. A further absorption with 'Small' group A type 28 removed all the type 28 antibodies. The serum was then tested for precipitins against $\mathrm{HCl}$ extracts of the strains from each group reacting with type 28 serum, and of four strains belonging to group $\mathrm{C}$ and not related to type 28 (Table 4). It will be seen that the serum DI0 contained antibodies peculiar to the homologous strain. The strain 6074, which resembled strain $\mathrm{D} 10$ in other respects, did not possess this antigen. Only one of the early samples of the D10 serum gave this result.

Table 4. To show the presence in strain D10, group C, type 28, of a specific precipitating antigen different from the type 28 antigen

\begin{tabular}{|c|c|c|c|c|}
\hline \multirow[b]{2}{*}{$\begin{array}{l}\text { M extracts prepared } \\
\text { from strain }\end{array}$} & \multicolumn{4}{|c|}{$\begin{array}{l}\text { Precipitin reactions with } 1010 \text { antiserum after } \\
\text { absorption with }\end{array}$} \\
\hline & Nil & $\begin{array}{l}\text { 'Small', } \\
\text { group A }\end{array}$ & $\begin{array}{l}\text { 'Azgazardah', } \\
\text { group C }\end{array}$ & $\begin{array}{l}\text { 'Small' and } \\
\text { 'Azgazardah' }\end{array}$ \\
\hline $\begin{array}{l}\text { 'Small', group A } \\
\text { D 10, group C } \\
\text { 'Azgazardah', group C } \\
\text { 6074, group C }\end{array}$ & $\begin{array}{l}++1++++^{*} \\
+++1++++ \\
++/ \operatorname{tr} \\
++1+++\end{array}$ & $\begin{array}{r}-1- \\
+1+ \\
++1+ \\
+1+\end{array}$ & $\begin{array}{c}++1+++ \\
++1+++ \\
-1- \\
++1+++\end{array}$ & $\begin{array}{l}-1- \\
+1++ \\
-1- \\
-1-\end{array}$ \\
\hline
\end{tabular}

* Symbols as in 'Table 1.

Thrce other group C strains, K 64, 'Chestle' and 'Austin', failed to react with the serum after absorption with either 'Small' or 'Azgazardah'.

\section{DISCUSSION}

Just as a $\mathbf{T}$ antigen of group $\mathbf{A}$ may be present in more than one type (Lancefield, 1940), so the M antigen of group A type 28 has now been shown to occur in strains from other groups, namely, B, C and G. Their behaviour in the laboratory and the clinical evidence supplied did not suggest that the possession of this antigen endowed these strains with greater pathogenicity than other streptococci of the same group. In spite of repeated passage through mice, 
none of the strains became virulent, nor could they be used as infecting strains in passive protection tests in mice. The use of mucin to enhance infectivity for protection tests was ruled out, because it prevents contact of the cocci with the antibodies. It is probable that certain of the streptococci possessing the type 28 antigen have another major antigen more characteristic of the strain. It has long been known that serological types exist within group B (Lancefield, 1934, 1938; Stableforth, 1932), and that the type-specific antigen is a polysaccharide; the typing of such strains is a routine procedure in veterinary work. The strain 3962 was typed by this method as III $b$. Another group B strain D $136 a$, received from D. R. Lippmann, was originally typed as a group B type III, and this strain also possessed group A type 28 antigen. These two strains thus possessed three precipitating antigens, the group-specific and the typespecific polysaccharides, and the type 28 antigen, a protein. The strain of Str. agalactiae, B2, which was used to make the type III $b$ antiserum with which strain 3962 reacted, did not show any relationship with type 28 . It is possible also that the group $\mathrm{C}$ strain D10 possesses another antigen peculiar to it, which was not found in the other group C strains 'Chestle', 'Austin' and K64; nor in strain 6074, although this strain also contained the type $28 \mathrm{M}$ antigen. The nature of this more specific antigen has not been investigated here, but Lancefield (1940-1) and Blakemore, Elliott \& Hart-Mercer (1941) have found evidence of its protein nature.

Watson \& Lancefield (1944) demonstrated that group A types 10 and 12 share a common $\mathbf{M}$ antigen, but it might be more correct to regard these two as one type, either 10 or 12, the $\mathrm{T}$ antigen of which varies for reasons not so far understood. It may be significant that the only $\mathbf{M}$ antigen so far found to be shared by strains in other groups should be the one which appears to have a different structure from the usual $\mathrm{M}$ antigen, as indicated by its resistance to tryptic digestion. The demonstration of the sharing of this unusual $\mathbf{M}$ antigen does not therefore contradict Lancefield's statements as to the specificity of the $M$ antigen of group $A$. It will be interesting if type 44 $M$ antigen is found in streptococci of other groups, since it also has. the same characteristics as those of group A type 28 (Lancefield, 1943).

I wish to thank Dr V. D. Allison and Dr S. D. Elliott for advice and criticism, and also Dr R. C. Lancefield for supplying some of the strains.

\section{REFERENCES}

Blakemore, F., Elliott, S. D. \& Hart-Mercer, J. (1941). Studies on suppurative polyarthritis (joint-ill) in lambs. J. Path. Bact. 52, 57.

LANCEFIELD, R. C. (1934). A serological differentiation of specific types of bovine haemolytic streptococci (group B). J. exp. Med. 59, 441.

LANCEFIELD, R. C. (1938). Two serological types of group B haemolytic streptococc1 with related, but not identical type specific substances. J. exp. Med. 67, 25.

LANCEFIELD, R. C. (1940). Type-specific antigens, M and T, or matt and glossy variants of group A haemolytic streptococci. J. exp. Med. 71, 539.

LANCEFIELD, R. C. (1940-1). Specific relationship of cell composition to biological activity of haemolytic streptococci. Harvey Lect. Series 36, 251-90. 
LANCEField, R. C. (1943). Studies of the antigenic composition of group A haemolytic streptococci. I. J. exp. Med. 78, 465.

StABleforth, A. W. (1932). The serological characters of mastitis streptococci. J. comp. Path. 45, 185.

Swift, H. F., Wilson, A. T. \& Lancefield, R. C. (1943). Typing group A haemolytic streptococci by $M$ precipitin reactions in capillary pipettes. J. exp. Med. 78, 127.

Tond, E. \& HewitT, L. E. (1932). A new culture medium for the production of antigenic streptococcal haemolysin. J. Path. Bact. 35, 973.

Watson, R. F. \& Lancefield, R. C. (1944). Studies of the antigenic composition of group A haemolytic streptococci. III. J. exp. Med. 79, 89.

(Received 7 March 1948) 